Dahlquist, A. \& Borgström, B. (I96r). Biochem. F. 8r, 4 I r.

Dahlqvist, A., Lindquist, B. \& Meeuwisse, G. (rg68). In Carbohydrate Metabolism and its Disorders, Vol. 2, p. 199 [F. Dickens, P. J. Randle and W. J. Whelan, editors]. London and New York: Academic Press.

Dawes, G. S. \& Shelley, H. J. (1968). In Carbohydrate Metabolism and its Disorders, Vol. 2, p. 87 [F. Dickens, P. J. Randle and W. J. Whelan, editors]. London and New York: Academic Press.

Eichholz, A. (1967). Biochim. biophys. Acta 135, 475 .

Eichholz, A. \& Crane, R. K. (1965). ₹. biophys. biochem. Cytol. 26, 687.

Eichholz, A. \& Crane, R. K. (1966). Fedn Proc. Fedn Am. Socs exp. Biol. 25, 656.

Fischer, E. H. \& Stein, E. A. (1960). The Enzymes and ed. Ch. 19, p. 313 [P. D. Boyer, H. A. Lardy and K. Myrbäck, editors]. London: Academic Press.

Fisher, R. B. \& Zachariah, P. (I961). F. Physiol, Lond, 158, 73.

Froesch, E. R. (1965). In Handbook of Physiology, Sect. 5. p. 28, [A. E. Renold and G. F. Cahill, editors]. Washington, D.C.: American Physiological Society.

Goodner, C. J. \& Tustison, W. A. (1964). Science, N.Y. 146, 770.

Hales, C. N. (I967). In Essays in Biochemistry, Vol. 3, p. 73 [P. N. Campbell and G. D. Greville, editors]. London: Academic Press.

Heinz, F. \& Lamprecht, W. (196r). Hoppe-Seylers Z., physiol. Chem. 324, 88.

Hellman, B. (1967). Diabetologia 3, 222.

Hers, H. G. (r960a). Biochim. Biophys. Acta 37, 120.

Hers, H. G. (1960b). Biochim. Biophys. Acta 37, 127.

Hers, H. G. \& Kusaka, T. (r953). Biochim. biophys. Acta Ir, 427.

Holdsworth, C. D. \& Dawson, A. M. (1964). Clin. Sci. 27, 37r.

Karam, J. H., Grodsky, G. M. \& Forsham, P. H. (1963). Diabetes 12, I 97.

Lindquist, B., Meeuwisse, G. \& Melin, K. (1962). Lancet ii, 666.

Mansford, K. R. L. (ig67). Proc. Nutr. Soc, 26, 27.

Mansford, K. R. L. (1968). Proc. R. Soc. Med. 6r, 816.

Mansour, T. E. (1963). F. biol. Chem. 238, 2285.

Monod, J., Changeux, J.-P. \& Jacob, F. (1963). F. molec. Biol. 6, 306.

Morgan, H. E., Henderson, M. J., Regen, D. M. \& Park, C. R. (1961). F. biol. Chem. 236, 253.

Morgan, H. E., Randle, P. J. \& Regen, D. M. (I959). Biochem. F. 73, 573.

Newsholme, E. A. \& Randle, P. J. (I96I). Biochem. F. 80, 655.

Newsholme, E. A. \& Randle, P. J. (1962). Biochem. F. 83, 387 .

Newsholme, E. A. \& Randle, P. J. (1964). Biochem. F. 93, 64r.

Owen, O. E., Sullivan, J. M. \& Cahill, G. F. Jr (1966). Clin. Res. I4, 35 I.

Passonneau, J. Y. \& Lowry, O. (1963). Biochem. biophys. Res. Commun. 13, 372.

Rabinowitz, D. \& Zierler, K. L. (1962). F. clin. Invest. 4r, 2173.

Renold, A. E. (1968). Advances in Metabolic Disorders 3, 49.

Salans, L. B., Knittle, J. L. \& Hirsch, J. (1967). F. clin. Invest. 46, I 112.

Semenza, G., Auricchio, S. \& Rubino, A. (1965). Biochim. biophys. Acta 96, 487.

Smyth, D. (1971). In Intestinal Transport of Electrolytes, Amino Acids and Sugars p. 52 [W, McD. Armstrong and A. S. Nunn, Jr, editors]. Springfield, Illinois: Thomas.

Ugolev, A. M. (I965). Physiol. Rev. 45, 555.

Walker, D. G. (rg68). In Carbohydrate Metabolism and its Disorders, Vol. I, p. 465 [F. Dickens, P. J. Randle and W, J. Whelan, editors]. London and New York: Academic Press.

Yudkin, J. (1968). In Carbohydrate Metabolism and its Disorders, Vol. 2, p. I69 [F. Dickens, P. J. Randle and W. J. Whelan, editors]. London and New York: Academic Press.

\title{
Digestion and metabolism of carbohydrates in the foetal and neonatal ruminant
}

\author{
By W. M. F. Leat, Agricultural Research Council, Institute of Animal Physiology, \\ Babraham, Cambridge
}

Carbohydrate metabolism during the development of the ruminant can conveniently be divided into four stages. (1) The intra-uterine stage when the foetus is supplied from the maternal circulation via the placenta with the glucose required 
for growth and metabolism. (2) The immediate postnatal period of about 2-3 weeks duration when the rumen is non-functional and digestion is characteristic of the non-ruminant mammal. Here the young ruminant is again dependent on its mother for carbohydrate, supplied this time in the form of milk lactose which must be hydrolysed in the gut before it is utilized. (3) A later intermediate stage from 3 to 8-12 weeks post partum when the rumen is developing and the supply of maternal milk begins to decrease. (4) The fully ruminant stage from 8 to 12 weeks post partum onwards when rumen fermentation can satisfy the energy requirements of the animal and the young ruminant can be weaned. At this stage, dietary carbohydrates are degraded in the rumen to volatile fatty acids and little, if any, glucose is absorbed from the gut; instead the mature ruminant must rely on gluconeogenesis for its supply of carbohydrate. Thus, in a space of $2-3$ months the young ruminant obtains its supply of carbohydrate by three distinct means and the metabolic implications of these changes are considerable.

\section{Carbohydrate metabolism in the foetal ruminant}

It is generally accepted that carbohydrate derived from the maternal circulation via the placenta is the most important source of energy in the developing foetus. Glucose is the major carbohydrate found in the foetal blood of many species but in ruminant animals fructose predominates. Bernard ( 1855$)$ reported the presence of a laevo-rotatory sugar in bovine allantoic fluid but final confirmation that this was fructose did not come until nearly a century later (Bacon \& Bell, 1948). Besides being present in allantoic fluid, fructose is found also in amniotic fluid and in foetal blood. The presence of fructose in foetal fluids and blood is apparently confined to the Ungulata (both odd- and even-toed) and Cetacea (Goodwin, 1956), which might suggest some common evolutionary descent (Huggett, I96r).

Most of the research on the origin of fructose has been done on the sheep but it is highly probable that the results also apply to other 'fructogenic' animals. It has been shown that glucose, during its transfer from mother to foetus, is partly converted in the placenta to fructose which appears in the foetal blood and fluids (Huggett, Warren \& Warren, 195I; Alexander, Andrews, Huggett, Nixon \& Widdas, 1955). Although glucose can pass the placenta in both directions, fructose cannot pass back into the maternal circulation; this results in an accumulation of fructose in the foetus. Foetal blood fructose concentrations are highest in early pregnancy and tend to fall with increasing gestational age (Fig. I) with the fructose being distributed between plasma and red blood cells (Hitchcock, 1949).

The formation of fructose from glucose in placenta probably occurs by the route shown below (Andrews, Britton, Huggett \& Nixon, 1960; Britton, Huggett \& Nixon, 1967).

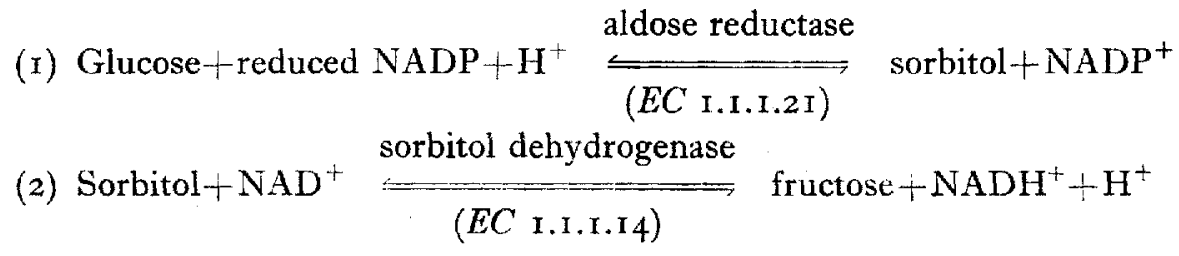




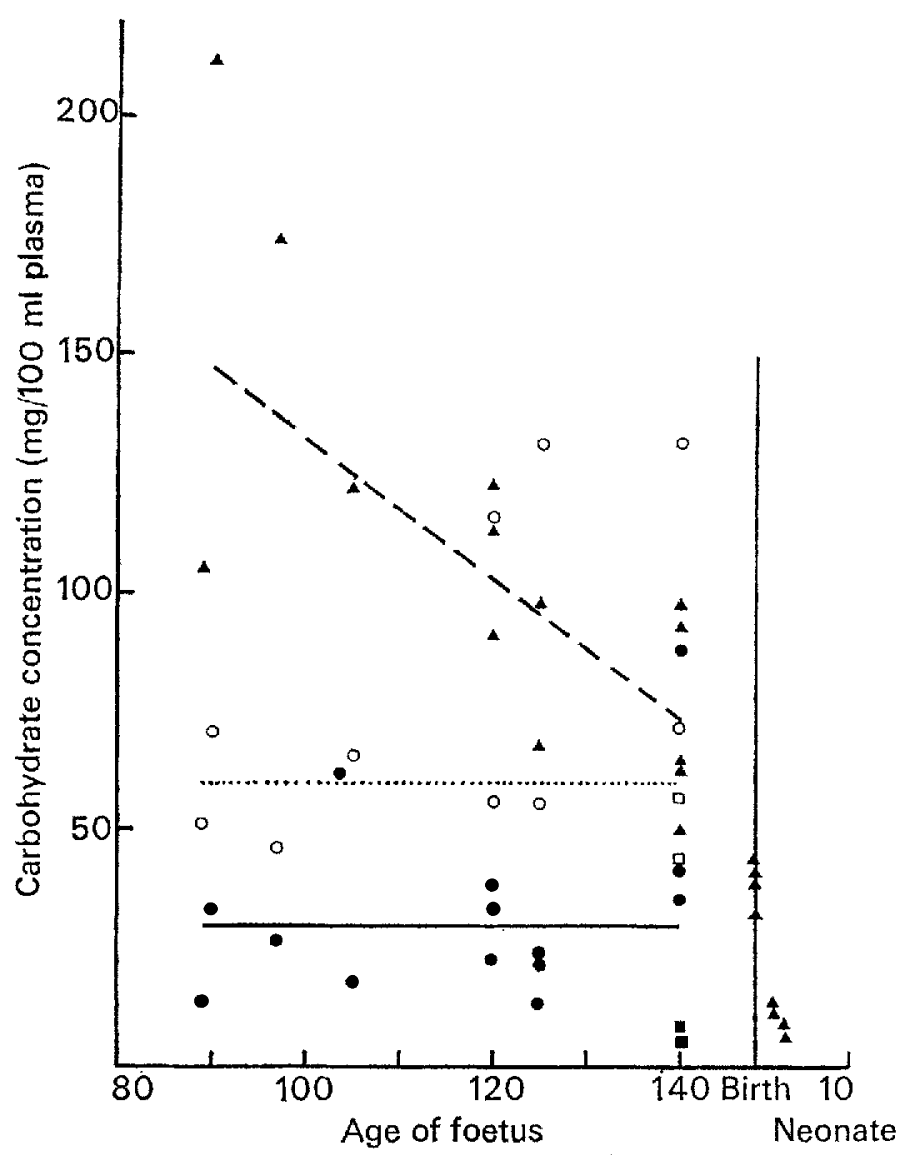

(d)

Fig. r. Plasma carbohydrate concentrations of foetal and neonatal sheep. $\mathbf{A}(--\longrightarrow-)$, foetal and neonatal lamb fructose; $(\longrightarrow$, foetal lamb glucose; $O(\ldots \ldots$.$) , maternal sheep glucose (mater-$ nal sheep fructose $<5 \mathrm{mg} / 100 \mathrm{ml}$ ); $\square$, plasma glucose of adrenalectomized ewes maintained with desoxycorticosterone acetate; $\square$, their foetuses.

There is still no satisfactory explanation for the function, if any, of fructose in these foetal fluids. Needham (1931) described the fructose question as 'the most enigmatic aspect of embryonic carbohydrate metabolism'; it remains so today. It is unlikely that fructose acts as a major reserve of carbohydrate in the foetus since the enzymes necessary for its utilization are absent from foetal liver. However, there is some evidence for fructose utilization by the foetus particularly when little glucose is available (Andrews et al. 1960; Scott, Setchell \& Bassett, 1967; Alexander, Britton \& Nixon, 1970) but oxidation of fructose is of minor significance compared to glucose. Barcroft (1946) was of the opinion that the osmotic pressure of fructose would encourage the flow of water into the foetus, but the total effect would be small.

The placenta is freely permeable to glucose by a process of facilitated transfer rather than by diffusion (Widdas, 1961). The glucose concentration in foetal sheep 
blood is less than that of fructose and fluctuates at about $50 \%$ of the maternal blood glucose concentration (Shelley \& Neligan, 1966; see Fig. 1). The glucose uptake by foetal lambs could account for a large part of the oxygen consumption and energy requirements of the foetus (Alexander, Britton \& Nixon, 1966). However, some glucose is required for the synthesis of fructose, glycogen and fat. Although free fatty acids can pass the placenta into the foetus, quantitatively they are of minor metabolic significance (Van Duyne, Parker, Havel \& Holm, r960). Since the ruminant placenta is probably impermeable to esterified lipids (Leat, I966), it appears that glucose is the major energy source for the foetus (Dawes, i968).

There is little glycogen in liver very early in gestation in the foetal sheep but levels rise substantially in the last half of gestation to reach high values $(80 \mathrm{mg} / \mathrm{g}$ wet weight) at parturition, which are about double adult values (Shelley, 1961). Glycogen is also stored in skeletal muscle (five times adult concentrations) and to a lesser extent in lung and heart; placental stores are low. This deposition of glycogen is associated with high activities of enzymes required in the synthesis of glycogen from glucose (Ballard \& Oliver, 1965). Even in the foetus, however, this glycogen store is labile and can be mobilized in time of stress (Alexander, Britton \& Nixon, 1970). Deposition of glycogen in the rat foetus is associated with the functional integrity of the pituitary and adrenal glands (see Jost, I 969 ). In adrenalectomized ewes maintained with desoxycorticosterone acetate to rectify sodium and potassium balance, blood glucose levels in the foetus are very low although fructose levels are normal (Fig. I, F. A. Harrison and W. M. F. Leat, unpublished observations).

The foetal requirement for glucose is high towards the end of gestation $(8-9 \mathrm{~g}$ glucose $/ \mathrm{kg}$ foetus daily) and can account for more than $30 \%$ of the glucose available to the mother (Kronfeld, 1958; Reid, 1968; but see Lindsay, 1971). Phillipson (1950) calculated that a single foetus accounted for $10.7 \%$ and twins for $17.1 \%$ of the basal metabolism of the non-pregnant ewe. The requirement of the foetus for glucose takes precedence over that of the ewe since in pregnancy toxaemia the carbohydrate status of the ewe is severely deranged whereas that of the foetus is relatively unaffected (Underwood, Curnow \& Shier, 1943). The plasma concentrations of glucose in foetuses from sheep suffering from pregnancy toxaemia appear normal but plasma fructose concentrations are low (less than $30 \mathrm{mg} / 100 \mathrm{ml}$ ) (E. J. H. Ford and W. M. F. Leat, unpublished observations).

\section{Carbohydrate metabolism after birth}

At birth the placental supply of carbohydrate from the mother ceases abruptly and the newborn has now to derive its carbohydrate from other sources such as milk and by gluconeogenesis. The fructose concentration in blood, which had remained high during the foetal period, declines rapidly to very low values within 24$48 \mathrm{~h}$ of birth (see Fig. I) (Cole \& Hitchcock, 1946). This is not the result of metabolism of fructose but rather of excretion into the urine (Shelley \& Dawes, 1962). Curiously, the necessary enzymes to metabolize fructose do not appear in the liver until the $5^{\text {th }}$ day post partum at which time no fructose remains in blood (Andrews et al. 1960 ; Ballard \& Oliver, 1965. ) 
Within $2 \mathrm{~h}$ of birth the plasma free fatty acid concentration in the lamb can rise as much as sixfold which may be a result of increased sympathetic activity at birth (Van Duyne et al. 1960; Van Duyne, 1966). Plasma glucose concentrations also rise after birth as a result of glycogenolysis associated with an increase in sympathetic efferent activity. In the calf the rise in plasma glucose post partum is not dependent on feeding, although suckling does exaggerate the increase (Comline \& Edwards, 1968). In the lamb, exposure to cold has a hyperglycaemic effect which is absent if the animal is maintained at room temperature (Alexander \& Mills, I968).

As in the foetus, the blood sugars of the newborn ruminant are distributed between the red blood cells and plasma but during the succeeding weeks the glucose content of the erythrocytes decreases to the very low values characteristic of adult ruminants (Reid, 1953; Leat, 1970). This seems to be a function of the red cell membrane itself rather than any hormonal change at this time; since if adult bovine erythrocytes are injected into a calf they maintain their low glucose content and do not acquire the glucose permeability of the neonatal animal (Johnson \& Stewart, 1968). Reid (1953) and Goodwin (1956) suggested that two types of red blood cells may be involved : a foetal cell high in glucose which is gradually replaced by an adult cell containing little or no glucose.

After the initial rise in blood sugar during the first week post partum, there is a gradual decline to adult values by $8-12$ weeks. Initially it was thought that this fall was associated with the rumen development but this is not now thought to be so (see Leat, 1970). The decrease in blood sugar with age is probably best explained by the decrease in red blood cell glucose, and by the decline in plasma glucose which reflects the diminishing intake of milk. In lambs the fasting concentrations of plasma glucose increase during the first week of life but then tend to decline during the period $3-8$ weeks post partum when there is a marked elevation in plasma free fatty acid concentrations (Leat, $197^{\circ}$ ). It appears therefore that, during the period $3^{-8}$ weeks post partum when the intake of milk is decreasing, the development of the rumen is not sufficiently advanced to prevent depletion of liver glycogen and mobilization of depot fat after an overnight fast.

After parturition, liver glycogen levels in the newborn ruminant fall rapidly to about $10 \%$ of foetal values within $2-3 \mathrm{~h}$ of birth, despite suckling, and these changes may be due to secretion of catecholamines (Edwards \& Silver, 1969). The liver glycogen values remain low for several days before rising to adult values 2-3 weeks post partum (Shelley, $196 \mathrm{r}$ ). This mobilization of glycogen after birth tides the animal over the intermediate period until the commencement of suckling.

During the first 8-12 weeks after birth the young ruminant changes from a non-ruminant to a ruminant-type digestion with a marked alteration in some aspects of carbohydrate metabolism (see Leat, 1970; and Edwards, 1970). In some ways the neonatal ruminant as it develops takes on the characteristics of diabetic man, for example in its response to intravenous glucose tolerance tests. In the foetal sheep, insulin plays a minor role in carbohydrate metabolism (Alexander, Britton, Cohen \& Nixon, 1970) and at birth insulin-release mechanisms appear to be 
deficient. Sensitivity to injected insulin is greatest immediately after birth but declines on development to become low in the adult ruminant.

These changes, together with the decreasing glucose utilization and size of glucose pool, suggest that the importance of glucose to the young ruminant decreases during the first 8-12 weeks of life. This is borne out by changes in enzyme activity of some key processes in carbohydrate metabolism during this stage of development, which reflect the carbohydrate status of the animal (see Leat, 1970). Thus, the young ruminant ingesting milk will absorb carbohydrates from the small intestine and enzymes are present in liver to catabolize glucose and to convert it to glycogen. As the young ruminant develops it ingests decreasing amounts of milk and, after weaning, little glucose will be absorbed from the gut since the dietary carbohydrates will be fermented in the rumen to volatile fatty acids. There is a reduced capacity for glucose oxidation by the liver and for conversion of glucose to glycogen in the mature ruminant. There is little net uptake of glucose by the liver of the adult ruminant and this is reflected in the negligible hepatic glucokinase (EC 2.7.1.2) activity. However, the adult liver is well equipped for gluconeogenesis, which is now the major source of glucose, and for the release of glucose into the blood stream. In the foetal and neonatal ruminant, glucose can also be converted into fat but in the adult ruminant the activity of ATP citrate lyase ( $E C C_{4} \cdot \mathbf{r}_{3} .8$ ), which is a key enzyme in the conversion of glucose to fat, is low. Glucose is very much at a premium in the adult ruminant which can ill afford the luxury of fat synthesis from carbohydrate. The decrease in glucose utilization and increased gluconeogenesis associated with the development of the young ruminant are also characteristics of the human diabetic state. These changes may be mediated through the glucose-fatty acid cycle (Randle, Garland, Hales \& Newsholme, 1963) by the action of volatile fatty acids being produced at this stage of rumen development.

\section{Digestion of carbohydrates}

The neonatal calf and lamb readily utilize lactose, glucose and galactose, whereas maltose is utilized only slightly, and fructose, sucrose and starch not at all (Dollar \& Porter, 1957; Walker, I959; Huber, 1969; Siddons, Smith, Henschel, Hill \& Porter, 1969). These findings correlate well with disaccharidase activities in the intestinal wall; $\beta$-galactosidase ( $E C$ 3.2.1.23) activity is high, $\alpha$-glucosidase ( $E C$ 3.2.1.20) low and sucrase absent. $\beta$-Galactosidase activity tends to decrease with age, $\alpha$-glucosidase remains unchanged and sucrase remains absent; these results agree well with data on utilization of carbohydrates, suggesting that the activity of intestinal disaccharidases is a controlling factor in disaccharide utilization (Siddons et al. I 969 ). In comparison, the pig, which at birth can only utilize glucose and lactose, develops the ability to utilize sucrose, dextrin and maltose at Io $\mathrm{d}$ of age (Dollar, Mitchell \& Porter, I957). However, in the older calf (4-6 months) there is appreciable digestion in the small intestine of starch and maltose (Henschel, Hill \& Porter, 1962), partly due to digestive enzymes and partly due to bacterial action. The rumen micro-organisms of a 3 -week-old lamb can digest as wide a variety of carbohydrates as the adult (Walker \& Walker, 196r). These results indicate that 
diets containing starch, dextrins, maltose or sucrose should be avoided for the young ruminant until such time as the rumen is functional, and that diets should be based on milk products or on predigested starch supplemented with $\alpha$-glucosidase. In the adult ruminant most dietary carbohydrates on normal diets are degraded in the rumen to volatile fatty acids and digestion in the small intestine becomes of lesser importance. It is of interest to note that in the human foetus all intestinal disaccharidases are active at 3 months and reach adult levels towards the end of gestation (Dahlquist \& Lindberg, 1966).

\section{REFERENCES}

Alexander, D. P., Andrews, R. D., Huggett, A. St G., Nixon, D. A. \& Widdas, W. F. (1955). $\mathcal{Y}$. Physiol., Lond. 129, 352.

Alexander, D. P., Britton, H. G., Cohen, N. M. \& Nixon, D. A. (I970). Biologia Neonat. 15, 142.

Alexander, D. P., Britton, H. G. \& Nixon, D. A. (1966). F. Physiol., Lond. 185, 382.

Alexander, D. P., Britton, H. G. \& Nixon, D. A. (1970). Q. Fl exp. Physiol. 55, 346.

Alexander, G. \& Mills, S. C. (1968). Biologia Neonat. 13, 53.

Andrews, W. H. H., Britton, H. G., Huggett, A. St G. \& Nixon, D. A. (1960). J. Physiol., Lond. 153, 199.

Bacon, J. S. D. \& Bell, D. J. (1948). Biochem. F. 42, 397.

Ballard, F. J. \& Oliver, I. T. (1965). Biochem. F. 95, 191.

Barcoft, J. (1946). Researches on Prenatal Life p. 23. Oxford: Blackwell Scientific Publications.

Bernard, C. (1855). Lecons de Physiologie Experimentale Appliquée a la Médecine p. 401. Paris: Baillière.

Britton, H. G., Huggett, A. St. G. \& Nixon, D. A. (1967). Biochim. biophys, Acta 136, 426.

Cole, S. W. \& Hitchcock, M. W. S. (1946). Biochem. F. 40, li.

Comline, R. S. \& Edwards, A. V. (1968). \%. Physiol., Lond. 198, 383.

Dahlquist, A. \& Lindberg, T. (1966). Clin. Sci. 30, $5 \times 7$.

Dawes, G. S. (1968). Foetal and Neonatal Physiology p. 2 10. Chicago: Year Book Medical Publishers Inc.

Dollar, A. M. \& Porter, J. W. G. (1957). Nature, Lond. 179, 1299.

Dollar, A. M., Mitchell, K. G. \& Porter, J. W. G. (1957). Proc. Nutr, Soc. 16, xii.

Edwards, A. V. (1970). In Physiology of Digestion and Metabolism in the Ruminant p. I80 [A. T. Phillipson, editor]. Newcastle upon Tyne: Oriel Press Ltd.

Edwards, A. V. \& Silver, M. (1969). Biologia Neonat. 14, r.

Goodwin, R. F. W. (1956). F. Physiol, London. 134, 88.

Henschel, M. J., Hill, W. B. \& Porter, J. W. G. (1962), Proc. Nutr. Soc. 22, v.

Hitchcock, M. W. S. (1949). F. Physiol., Lond. 108, 117.

Huber, J. T. (1969). I. Dairy Sci. 52, 1303.

Huggett, A. St G, (196r). Br. med. Bull. r7, 1z2.

Huggett, A. St G., Warren, F. L. \& Warren, N. V. (1951). F. Physiol., Lond. 113, 258.

Johnson, R. B. \& Stewart, W. E. (1968). F. Dairy Sci. 50, r828.

Jost, A. (1969). In Foetal Autonomy. Ciba Foundation Symposium p. 79 [G. E. W. Wolstenholme and M. O'Connor, editors]. London: J. \& A. Churchill Ltd.

Kronfeld, D. S. ( 958 ). Cornell Vet. 48, 394.

Leat, W. M. F. (1966). Biochem. $\mathcal{9} .98,598$.

Leat, W. M. F. (1970). In Physiology of Digestion and Metabolism in the Ruminant p. 2x1 [A. T. Phillipson, editor]. Newcastle upon Tyne: Oriel Press Ltd.

Lindsay, D. B. (1971). Proc. Nutr. Soc. 30, 272

Needham, J. (193I). Chemical Embryology Vol. 2, p. 1054. London: Cambridge University Press.

Phillipson, A. T. (1950). In Toxaemias of Pregnancy. Ciba Foundation Symposium p. 94 [J. Hammond, F. J. Browne and G. E. W. Wolstenholme, editors]. London: J. A. Churchill Ltd.

Randle, P. J., Garland, P. B., Hales, C. N. \& Newsholme, E. A. (1963). Lancet i, $78_{5}$.

Reid, R. L. (1953). Aust. F. agric. Res, 4, 213.

Reid, R. L. (1968). Adv. vet. Sci. 12, 163.

Scott, T. W., Setchell, B. P. \& Bassett, J. M. (I967). Biochem. J. 104, ro4o.

Shelley, H. J. ( I 96r). Br. med. Bull. 17, 137.

Shelley, H. J. \& Dawes, G. S. (1962). Nature, Lond. 194, 296.

Shelley, H. J. \& Neligan, G. A. (I966). Br. med. Bull. 22, 34.

Siddons, R. C., Smith, R. H., Henschel, M. J., Hill, W. B. \& Porter, J. W. G. (1969). Br. Y. Nutr. 23, 333. 
Underwood, E. J., Curnow, D. H. \& Shier, F. L. (1943). Aust. vet. J. 19, I64.

Van Duyne, C. M. (1966). Biologia Neonat. 9, 115.

Van Duyne, C. M., Parker, H. R., Havel, R. J. \& Holm, L. W. (1960). Am. f. Physiol. 199, 987.

Waiker, D. M. (1959). F. agric. Sci., Camb. 53, 374.

Walker, D. M. \& Walker, G. J. (1961). F. agric. Sci., Camb. 57, 271.

Widdas, W. F. (1961). Br. med. Bull. $\times 7,107$.

\section{Carbohydrate digestion and glucose supply in the gut of the ruminant}

\section{By J. D. Sutton, National Institute for Research in Dairying, Shinfield, Reading $R G_{2}{ }_{9} A T$}

The ruminant is able to digest and utilize a wider range of carbohydrates than most other mammals, yet the means whereby it carries out this digestion also ensures that it may, during periods of high productivity, suffer from a shortage of glucose. Indeed the plight of the high-producing ruminant is not so very different from that of the ancient Mariner who had 'Water water every where. Nor any drop to drink.' The basic reason for this shortage of glucose is that some $90 \%$ of the digestion of carbohydrates is by fermentation to short-chain fatty acids (volatile fatty acids (VFA)) by the bacteria and protozoa of the rumen and large intestine. Thus, only small amounts of glucose, derived mainly by hydrolysis of starch in the small intestine, are absorbed from the gut, and to meet its glucose requirements the ruminant relies heavily upon gluconeogenesis from the propionic acid and microbial protein produced by fermentation in the rumen.

In the following discussion, those aspects of carbohydrate digestion recently reviewed for the Society by Armstrong \& Beever (1969) will be covered only briefly.

\section{Processes of carbohydrate digestion}

Rumen. The first form of digestion which carbohydrates undergo involves an anaerobic fermentation in the rumen. Polysaccharides are hydrolysed and the resulting hexoses and pentoses are then oxidized to acetic acid and various reduced products, in particular propionic acid, $\mathrm{n}$-butyric acid and methane. These products are formed in widely different proportions although, so far as is known, all carbohydrates are fermented by a common pathway, the Embden-Meyerhof glycolysis system, to pyruvate. It is in the further metabolism of pyruvate that the differences in products arise (Baldwin, I965).

The products formed during fermentation are basically the resultant of the interaction between the microbial population and the substrate. Such relatively small differences in substrates as exist between glucose, galactose and xylose result in the formation of widely different proportions of VFA (Sutton, 1968), but there is no consistent relation between a substrate and the products of its fermentation as $3 \circ(3) 4$ 